\title{
Comunicação e Gênero no Brasil: discutindo a relação
}

\author{
COMMUNICATION AND GENDER IN BRAZIL: DISCUSSING THE \\ RELATIONSHIP
}

\section{COMUNICACIÓN Y GÉNERO EN BRASIL: DISCUTIENDO LA RELACIÓN}

\section{Ana Carolina D. Escosteguy}

Professora do Programa de Pós-Graduação em Comunicação da UFSM, Dra. em Ciências da Comunicação pela ECA/USP, Pesquisadora do CNPq, carolad2017@gmail.com

\section{RESUMO}

Trata-se de identificar vinculações entre os estudos de comunicação e questões de gênero, no Brasil. Em chave histórica, destacam-se singularidades dos debates teóricos associados ao feminismo brasileiro e seu impacto na agenda de pesquisa da Comunicação. Desse modo, observam-se modificações pelas quais a pesquisa e suas categorias foram passando ao longo de 1970 até 2015. A partir daí possivelmente se constitua novo impulso ainda em processo. $\mathrm{Na}$ arrancada inaugural (1970/1980), sobressai o uso sistemático da categoria mulher; no segundo impulso (1990), embora o termo gênero seja acionado, funciona mais como etiqueta; no terceiro (2000-2015), é a crítica ao pós-feminismo que desponta, evidenciando a primeira convergência entre Sul e Norte. Por fim, o último impulso recente se desenha a partir da primavera feminista e o horizonte aberto pela explosão dos feminismos, impulsionado pelas novas mídias digitais. Contudo, não dá para subestimar a formação na década de 2010 de uma cruzada moral contra o reconhecimento da diversidade de gênero e sexualidade, bem como a ascensão de uma extrema-direita que potencializa e promove um discurso antifeminista.

PALAVRAS-CHAVE: Comunicação; Gênero; Brasil.

Dossiê Crise, Feminismo e Comunicação - https://revistaecopos.eco.ufrj.br/

ISSN $2175-8689$ - v. 23, n. 3, 2020

DOI: 10.29146/eco-pos.v23i3.27643 


\section{ABSTRACT}

This paper identifies linkages between media studies and gender issues in Brazil. The perspective assumed is historical, stressing the singularities of the theoretical debates associated with Brazilian feminism and their impact on media studies research. In this way, we observe the changes that the research and its categories were going through in the period 1970 to 2015. A possible new impulse may then be created, still in process. In the opening run (1970/1980), the systematic use of woman category stands out; in the second (1990), although the term gender is triggered in media studies, it functions more as a label; in the third (2000-2015), it is the critique of post-feminism that emerges, evidencing the first convergence between South and North, in terms of media studies. Finally, the last one is drawn from the feminist spring and the horizon opened by the explosion of feminisms driven by the new digital media. However, it is not possible to underestimate the formation in the 2010's decade of a moral crusade against the recognition of sexual and gender diversity, as well as the rise of an extreme right-wing that potentiates an anti-feminist discourse.

KEYWORDS: Communication; Gender; Brazil.

\section{RESUMEN}

El artículo intenta identificar vínculos entre estudios de comunicación y de género en Brasil. En términos históricos, se destacan los debates teóricos asociados al feminismo brasileño y su impacto en la agenda de investigación en Comunicación. De esta manera, hay cambios por los que pasó la investigación y sus categorías desde 1970 hasta 2015. A partir de entonces, puede que esté en proceso un nuevo impulso. En el impulso inaugural (1970/1980), se destaca el uso sistemático de la categoría mujer; en el segundo impulso (1990), aunque se utiliza el término género, funciona más como una etiqueta; en el tercero (2000-2015), es la crítica al posfeminismo que emerge, mostrando la primera convergencia entre Sur y Norte. Finalmente, el último impulso recién tiene inicio con la primavera feminista y el horizonte abierto por la explosión de los feminismos, impulsados por los nuevos medios digitales. Sin embargo, no es posible subestimar la formación en la década del 2010 de una cruzada moral contra el reconocimiento de la diversidad sexual y de género y también el surgimiento de una extrema derecha que potencia un discurso antifeminista.

PALABRAS CLAVE: Comunicación; Género; Brasil.

Dossiê Crise, Feminismo e Comunicação - https://revistaecopos.eco.ufrj.br/

ISSN $2175-8689$ - v. 23, n. 3, 2020

DOI: 10.29146/eco-pos.v23i3.27643 


\section{Introdução}

O esforço neste texto está concentrado na discussão das relações entre o campo da Comunicação e questões de gênero, no Brasil ${ }^{1}$. Em chave histórica, procuro destacar singularidades do desenvolvimento de debates teóricos associados ao feminismo brasileiro e seu impacto na configuração de uma agenda de pesquisa no âmbito da Comunicação. Justifico a opção por esse tipo de olhar histórico -, sobretudo, por dois motivos. Em primeiro lugar, pela escassez de documentação que faça memória a respeito do percurso da problemática na área até ganhar a visibilidade exponencial de hoje e, em segundo, porque tal viés registra as modificações pelas quais os marcos teóricos e a pesquisa e suas categorias conceituais foram passando ao longo do período em análise.

Reconheço que meu posicionamento é situado, crítico e parcial. Essa postura dá margem à visibilidade das particularidades da voz desta pesquisadora. Ocupo um lugar privilegiado social e culturalmente - sou mulher branca, cisgênero e heterossexual. Falo, também, como docente que atua, na Comunicação, desde 1986, com formação acadêmica na mesma área. E meu percurso intelectual está associado à afinidades com uma vertente de estudos culturais.

No âmbito da produção do conhecimento, mais propriamente da pesquisa acadêmica, reconhecer esse posicionamento significa evidenciar um determinado ponto de vista e, em certa medida, refutar a neutralidade epistemológica. Esse viés possibilita dar adesão a premissa de "pensar a importância epistêmica da identidade, pois reflete o fato de que experiências em localizações são distintas e

\footnotetext{
1 Um longo percurso de diálogo e partilha de preocupações com muitas alunas de graduação e pósgraduação fez possível este artigo. Sem espaço para nominá-las uma a uma, registro meu muito obrigada pela rede de afetos e trocas acadêmicas que estabelecemos em distintos momentos de nossas vidas. Nesta última etapa de revisão e atualização, agradeço especialmente as contribuições de Lígia Lana. Foi, também, muito importante a discussão no Grupo de Trabalho Comunicação, Gêneros e Sexualidades (2019) do XXVIII Encontro Anual da Compós onde apresentei uma versão deste texto. E, antes disso, a palestra que ministrei em 2018, Mídia e gênero: uma narrativa críticoreflexiva. Minha gratidão à equipe da organização do I Aquenda de Comunicação, Gêneros e Sexualidades e, em especial, a Fernanda Nascimento da Silva, pelo convite e estímulo para pensar estas questões.
}

Dossiê Crise, Feminismo e Comunicação - https://revistaecopos.eco.ufri.br/

ISSN $2175-8689$ - v. 23, n. 3, 2020

DOI: 10.29146/eco-pos.v23i3.27643 
que a localização é importante para o conhecimento", como diz Djamila Ribeiro ${ }^{2}$ (2017, p. 29).

Ainda, outras marcas espaciais e temporais da origem do vínculo e do interesse no tema também conformam meu posicionamento. Meu primeiro contato com questões referentes ao feminismo articulado à minha área de atuação ocorreu via a leitura do texto "Learning from experience: Cultural Studies and Feminism", de Ann Gray (1997), coordenadora do Departamento de Estudos Culturais da Universidade de Birmingham (Inglaterra) onde fui realizar meu doutoradosanduíche, em 1998. 0 impacto do argumento de que a contribuição feminista no âmbito dos estudos culturais e, especialmente, nos estudos de recepção, estava rasurada e invisibilizada enquanto tal, deslocou minha atenção para esse problema.

Contudo, ganhou proeminência somente após o doutoramento (2001); depois, como docente, na graduação dando aulas esparsas nos programas de disciplinas que permitiam a inclusão de tal tema e, por fim, na orientação das primeiras monografias. Posteriormente, o processo se repetiu na pós-graduação. Igualmente, como tópico em determinados cursos e, mais adiante, na orientação de dissertações e teses. Portanto, entendo que é fundamentalmente no espaço da docência e da pesquisa onde exerço minha prática política feminista.

É desse lugar que costuro meus apontamentos sobre as relações entre a Comunicação e questões de gênero. Porém, antes é necessário explicitar algumas balizas deste relato. Em primeiro lugar, adoto a denominação campo da Comunicação tal como se encontra acordado na academia brasileira, isto é, com fronteiras fluidas onde há tanto a vigência de uma centralidade na mídia quanto um olhar mais alargado que abrange processos interacionais variados. No que diz respeito ao conceito de gênero, ele surgiu, em meados dos anos 1970, com o propósito de "distinguir e separar" sexo de gênero. 0 primeiro entendido como "categoria analítica marcada pela biologia e por uma abordagem essencializante da

\footnotetext{
2 Utilizo o prenome das autoras citadas ao longo do texto, com o objetivo de chamar a atenção para uma produção intelectual que muitas vezes fica encoberta pelo sobrenome que se apresenta como neutro.
}

Dossiê Crise, Feminismo e Comunicação - https://revistaecopos.eco.ufrj.br/

ISSN 2175-8689 - v. 23, n. 3, 2020

DOI: 10.29146/eco-pos.v23i3.27643 
natureza, ancorada no biológico". O segundo compreendido como "dimensão que enfatiza traços de construção histórica, social e sobretudo política que implicaria análise relacional" (Marlise Matos, 2008, p. 336).

Se, em um primeiro momento, sua formulação é atribuída ao pensamento feminista, a efervescência de ativismos políticos, nos anos 1970-1980, especialmente em torno de identidades lésbicas e gays fomentou o debate teórico produzindo novos olhares sobre a categoria gênero e a problemática das sexualidades. Esses percursos se potencializaram na contemporaneidade via intersecções entre novos ativismos LGBTQI+ - destacando-se a emergência política e cultural de transexuais, outras perspectivas teóricas, metodológicas e epistemológicas feministas e, também, transformações sociais. Dado a existência de uma diversidade de desdobramentos teóricos nos estudos de gênero, priorizo uma perspectiva feminista no que diz respeito ao seu compromisso com a afirmação das mulheres como sujeito político e do conhecimento sem deixar de reconhecer as identidades LGBTQI+.

Ao mesmo tempo, é importante lembrar que no contexto brasileiro houve um impacto diferenciado e desigual do feminismo, por um lado, nas ciências humanas e sociais e, por outro, na comunicação. Nesta última área, sua presença foi inexpressiva até recentemente. Dois exemplos podem ser usados, entre tantos outros, para referendar esse argumento.

Vinte anos depois do I Concurso de Dotações para Pesquisas sobre Mulheres que ocorreu em 1978, o livro Tempos e lugares de gênero (Cristina Bruschini e Celi Pinto, 2001) que publica o resultado do VIII Concurso de Dotações para Pesquisas sobre Mulheres e Relações de Gênero, realizado em 1998, apresenta textos oriundos da História, da Sociologia, da Antropologia e do Direito. A diversidade disciplinar é saudada efusivamente na coletânea, dado que as ciências sociais sempre foram muito resistentes a esse tipo de estudo, conforme Celi Pinto (2003). Mesmo que se reconheça como positiva a presença de pesquisas de distintas origens disciplinares, contribui também para revelar a ausência da Comunicação.

Outro indício do desinteresse pela temática é referendado pela criação do

Dossiê Crise, Feminismo e Comunicação - https://revistaecopos.eco.ufrj.br/

ISSN $2175-8689$ - v. 23, n. 3, 2020

DOI: 10.29146/eco-pos.v23i3.27643 
GT Comunicação e Mulher da INTERCOM em 1996, aproximadamente vinte anos depois da fundação dessa associação, em 1977. Dois anos mais tarde, em 1998, ele passa a denominar-se Comunicação e Relações de Gênero. Porém, em 2000, encerra seu ciclo de atividades, transformando-se apenas em temática do GT Comunicação e Cultura das Minorias. Este último, apesar de sua importância, conclui suas atividades em 2006. E, dois anos mais tarde, em 2008, é criado o Grupo de Pesquisa Estéticas Políticas do Corpo e Gêneros dentro da Divisão Temática Comunicação, Espaços e Cidadania, permanecendo em funcionamento até a atualidade. ${ }^{3}$ As sucessivas mudanças revelam que as questões de gênero não se assentam na Comunicação, até pelo menos a virada de milênio quando, paulatinamente, vão ganhar mais força.

Essa trajetória contrasta com a extrema simpatia e visibilidade que esse tema adquire na área no final da segunda década do século XXI devido ao fortalecimento dos feminismos na arena pública e acadêmica. Ilustra essa virada a temática do $41^{0}$ Congresso Brasileiro de Ciências da Comunicação - INTERCOM, Desigualdades, gêneros e comunicação, realizado em setembro de 2018. Esse mesmo tema repercutiu nos cinco congressos regionais da entidade. ${ }^{4}$ Ainda outro sinal da crescente atenção ao tema no campo é a criação do GT Comunicação, Gêneros e Sexualidades, em 2018, no XXVII Encontro Anual da Associação Nacional de Programa de Pós-Graduação em Comunicação - Compós. Sendo assim, a primeira rodada de debates desse grupo, no âmbito dessa entidade, ocorreu apenas em 2019.

Enfim, organizo esta narrativa por meio de um entrecruzamento de aspectos históricos do feminismo brasileiro, atentando sobretudo ao relato a respeito de Celi Pinto ${ }^{5}$ (2003), com anotações esparsas sobre produções midiáticas atravessadas por esse tema que causaram repercussão na sociedade no momento de sua circulação. Sobre a história dos feminismos, não levo em conta

${ }^{3}$ Disponível em: http://www.portalintercom.org.br/eventos1/gps1/ementas-dtsgps. Acesso em: 3 ago. 2020.

4 Intercom Centro-Oeste, Sudeste, Norte, Sul e Nordeste.

5 A periodização sintética apresentada por Celi Pinto, privilegiada neste artigo, dentre outras possibilidades, permite compreender uma formação (Williams, 2011) onde se desenvolvem determinados debates político-culturais fortemente vinculados a conjunturas particulares.

Dossiê Crise, Feminismo e Comunicação - https://revistaecopos.eco.ufrj.br/

ISSN $2175-8689$ - v. 23, n. 3, 2020

DOI: 10.29146/eco-pos.v23i3.27643 
objetivamente a classificação corrente das "ondas" do feminismo já que esta apaga a singularidade do nosso contexto histórico, sociopolítico e cultural. Entre nós, tanto o movimento quanto o debate teórico foi se configurando de modo próprio, ainda que em diálogo com outros feminismos. ${ }^{6}$

A respeito da escolha de representações ${ }^{7}$ que circularam na televisão e na imprensa nacional, expressando sexismo e violência contra as mulheres e, de modo mais isolado e raro, ruptura e crítica a esses mesmos padrões, ela se deve ao entendimento de que as preocupações iniciais do relacionamento entre Comunicação e estudos de gênero desenvolveram-se, na sua origem, a partir de três zonas prioritárias: a imagem das mulheres na mídia, sua recepção/consumo por mulheres enquanto audiências e a participação das mulheres na mídia como produtoras, jornalistas, etc. Portanto, como avalia Carolina von Lurzer (2018, p. 263), "se bem os estudos comunicacionais não fiquem reduzidos aos meios de comunicação - seja em suas discursividades, rotinas de produção ou consumo este viés é uma marca de origem daqueles que pensam a comunicação a partir do gênero."

Em termos da pesquisa em Comunicação, tomo como ponto de partida os anos 1970, já que antes disso praticamente não existe no Brasil o entendimento de que a comunicação podia ser objeto de estudo acadêmico. É nesse período, também, que se consolida um mercado de bens culturais de massa e que se expande o sistema de seu ensino. "No Brasil, os estudos acadêmicos de comunicação têm seu ponto de partida em meio à época do chamado milagre econômico, ocorrido entre 1969 e 1973" (Rudiger, Escosteguy, 2017, p. 361). É a partir daí que identifico quatro impulsos nas relações entre os estudos de comunicação e questões de gênero: a arrancada inaugural, nos anos 1970 e 1980; o

\footnotetext{
${ }^{6}$ Atualmente, os fluxos teóricos das teorias feministas entre Norte e Sul, bem como na direção inversa, adquiriram relevância como objeto de estudo. As configurações particulares dessa circulação global constituem temática específica e, portanto, não há espaço aqui para seu devido tratamento. Contudo, no âmbito da comunicação, há relatos pessoais de que se toma conhecimento no estrangeiro de uma vertente de estudos de mídia e gênero, seja nos Estados Unidos, seja na Europa - ver Ana Carolina Escosteguy (2012) e as entrevistas de Esther Hamburger e Heloisa Buarque de Almeida em Clara Meirelles (2009).

${ }^{7}$ A seleção dos textos midiáticos não pretende sistematicidade nem exaustividade; está composta por exemplos dispersos.
}

Dossiê Crise, Feminismo e Comunicação - https://revistaecopos.eco.ufrj.br/

ISSN $2175-8689$ - v. 23, n. 3, 2020

DOI: 10.29146/eco-pos.v23i3.27643 
segundo impulso nos 1990; o terceiro, dos anos 2000 até 2015 e, por fim, o que está em curso a partir do que se convencionou chamar "a primavera feminista".

$\mathrm{Na}$ arrancada inaugural, sobressai o uso sistemático da categoria mulher ${ }^{8}$, desdobrado na preocupação com sua imagem na mídia e como os meios atuam sobre ela. Embora seja flagrante a diferença entre a conjuntura nacional dos 1970, marcada pela ditadura, e a dos 1980, pela redemocratização, nesse período se faz muito a denúncia da ação da mídia na circulação de sentidos que não "refletem" a situação da "verdadeira" mulher.

0 termo gênero marca presença nos estudos de mídia nos anos 1990, ainda que não ganhe densidade conceitual, funcionando muito mais como mera etiqueta. Portanto, o segundo impulso revela uma frouxa vinculação aos debates já avançados em outras áreas disciplinares, principalmente, nas ciências sociais. Enquanto uma série de ganhos se instalaram no país no que diz respeito à situação das mulheres, o movimento feminista em si mesmo parecia ter arrefecido em vitalidade. Coincidem nessa análise, por exemplo, Bila Sorj (2018), em depoimento sobre seus vínculos com o feminismo brasileiro, e Celi Pinto (2003). Esta última assinala que, na virada do milênio, aparecem, inclusive, indícios antifeministas ou pós-feministas, associados à circulação de ideias que vinculam o feminismo com algo antigo e superado.

É na primeira década do século XXI que a querela entre "o fim" do feminismo e sua popularização revela-se falaciosa. Em termos teóricos, os estudos de mídia evidenciam, fortemente, a incorporação de uma crítica ao pós-feminismo. Aqui configura-se o terceiro impulso (2000-2015), despontando a primeira convergência entre Sul e Norte. Por fim, o quarto impulso recém se desenha a partir da "primavera feminista", ou seja, de grandes manifestações feministas como a Marcha das Margaridas, das Mulheres Negras, do Empoderamento Crespo, entre outras, e o horizonte aberto pela explosão dos feminismos, impulsionada pelas novas mídias digitais e por movimentos sociais negros, de favelas e de diversidade

8 Isso ocorre em sintonia com os movimentos sociais da época e, também, com a produção acadêmica de outras áreas.

Dossiê Crise, Feminismo e Comunicação - https://revistaecopos.eco.ufrj.br/ ISSN $2175-8689$ - v. 23, n. 3, 2020

DOI: 10.29146/eco-pos.v23i3.27643 
sexual. ${ }^{9}$ Apesar disso, ocorre a formação nesta década de uma cruzada moral contra o reconhecimento das diferenças de gênero e sexualidade (Baliero, 2018), culminando com a última campanha presidencial (2018). Portanto, nota-se uma ofensiva das forças conservadoras e a escalada de um enfurecido discurso antifeminista. ${ }^{10}$

A seguir detalho cada um desses impulsos em seção específica.

\section{Anos 1970/1980: a imagem da mulher na mídia}

A transição da década de 1960 para a de 1970 foi marcada pela ditadura militar. O clima de repressão não abrangeu estritamente a esfera política, mas também a moral. Mesmo assim, a modernização da sociedade e os movimentos de contracultura vindos "de fora", propiciaram terreno fértil para a aglutinação de iniciativas "de dentro" em oposição aos padrões vigentes. Entre elas, destacou-se o movimento feminista que combinou duas frentes de luta. Ao mesmo tempo que se organizava em defesa da especificidade da condição da mulher, estabelecia uma profunda ligação com a luta contra a ditadura militar. Isto desembocou num tensionamento permanente entre dois vetores: aquele associado às lutas que davam ênfase à sexualidade, ao corpo e ao prazer versus aquele outro que priorizava a luta de classes e pela democracia. Esse atrito avultava porque as organizações de esquerda compreendiam as reivindicações específicas desse movimento como "capaz[es] de comprometer o vigor da batalha contra o que seria o verdadeiro inimigo comum" (Pinto, 2003, p. 45).

Além desse embate e dentro das fileiras do combate ao autoritarismo, o movimento feminista e as feministas sofreram ataques reacionários. É exemplar a esse respeito o desconforto gerado pela cobertura da visita de Betty Friedan, autora de $A$ mística feminista (1963), realizada pelo O Pasquim, quando veio ao

\footnotetext{
9 Ver, por exemplo, registros das múltiplas frentes feministas em Heloísa Buarque de Hollanda, Explosão feminista - Arte, cultura, política e universidade (São Paulo: Companhia das Letras, 2018). 10 A campanha online de Sarah Winter contra a vinda de Judith Butler ao Brasil, em 2017, ilustra essa posição. Ver Baliero (2018).
}

Dossiê Crise, Feminismo e Comunicação - https://revistaecopos.eco.ufrj.br/ ISSN $2175-8689$ - v. 23, n. 3, 2020

DOI: 10.29146/eco-pos.v23i3.27643 
Brasil, em abril de 1971.11 A capa da edição semanal (n. 94, 22 a 28 de abr. 1971) desse jornal alternativo, simpático com a esquerda da época, estampou a seguinte chamada: "Desculpe D. Betty, mas nós vamos dar cobertura às furadoras da greve de sexo". Entre os múltiplos sentidos que podem ser atribuídos ao título, de modo amplo, encontra-se a desqualificação e a provocação às feministas na luta pelo controle sobre seus corpos.

Através de diversos excertos que circularam entre 1969 a 1976, a equipe do jornal taxava as feministas como despeitadas, mal-amadas, agressivas, malhumoradas, solteironas, pouco inteligentes, entre outros rótulos. "Não poucas matérias registram tais 'qualidades' das feministas, o que aproxima os libertários desse jornal do momento da contracultura dos misóginos de outras épocas" (Soihet, 2005, p. 595).

Porém, a imprensa independente e/ou alternativa e feminista teve papel fundamental nessa etapa. Entre as experiências que se destacaram, estão Brasil Mulher (1975-1980) e Nós, Mulheres (1976-1978). O uso desses meios como forma de atividade política feminista foi expressivo, no período do regime militar, evidenciando o reconhecimento da importância da mídia na ação transformadora almejada pelo movimento.

Em análise temática sobre o conteúdo desses jornais, Amélia Teles e Rosalina Leite (2013) observam a convivência entre temas conjunturais (entre eles, custo de vida, organização popular, anistia e denúncia de presos políticos) e específicos (creche, saúde da mulher; violência; discriminação racial, aborto, divórcio). Ou seja, o elenco temático reforça a "dupla militância" - a ação contra a ditadura e em defesa de direitos próprios à causa feminista, um elemento que contribui para a constituição de uma de nossas diferenças em relação ao feminismo do Norte.

${ }^{11}$ A cobertura midiática, de um modo geral, assumiu o mesmo tom. A entrevista de Betty Friedan à revista Veja (21 de abril de 1971), nas famosas páginas amarelas, documenta o ataque da imprensa hegemônica. 0 primeiro parágrafo da matéria assim a descrevia: "Baixa, de nariz pronunciado, cabelos grisalhos e voz quase rouca, Betty Friedan, não possui tipo físico atraente." Uma das raras vozes que se manifestou em contraposição ao tratamento dado pela mídia nacional à intelectual norte-americana foi Carmem da Silva, em sua coluna A arte de ser mulher, na revista Cláudia (n 18, julho de 1971).

Dossiê Crise, Feminismo e Comunicação - https://revistaecopos.eco.ufri.br/

ISSN 2175-8689 - v. 23, n. 3, 2020

DOI: 10.29146/eco-pos.v23i3.27643 
Em geral, nessas condições, reflexões e pesquisas de caráter feminista assumiam essas mesmas questões, desinteressando-se por temas vinculados à cultura popular de massa. Contudo, há exceções. Ainda que não declaradamente feminista, o que era usual na época, a pesquisa de Eclea Bosi, Cultura de massa e cultura popular: Leituras de operárias ([1973] 1978), realizada no início dos 1970, foi pioneira na exploração do universo vivido pela mulher operária e no significado que a cultura adquire em uma sociedade industrial.

Apoiada em categorias analíticas inspiradas pelo marxismo, como a de classe social, o livro adentra no universo das leituras de fotonovelas, jornais, revistas e livros de operárias de uma fábrica na zona oeste de São Paulo. Pesquisa de caráter etnográfico, segue as pistas de Richard Hoggart, revelando uma aproximação ao estudo de práticas de consumo cultural. Desse modo, posiciona-se na contramão das pesquisas em comunicação da época, mais de corte semiológico, funcionalista ou frankfurtiano. Voltando-se para o contexto social no qual se constitui a dura realidade da vida cotidiana, aborda a leitura de mídia impressa junto a operárias como uma atividade que se inscreve em suas vidas e que, embora seja um produto da cultura de massa, não altera completamente o tecido das relações concretas de que é feito seu cotidiano.

Igualmente, é importante assinalar o peso do conservadorismo e a reação às pautas feministas que se manifestavam de modo contundente na mídia dessa época. A cobertura jornalística do assassinato de Ângela Diniz por Doca Street, em dezembro de 1976, e seu primeiro julgamento, em outubro de 1979, são paradigmáticos a esse respeito.

De vítima, Ângela Diniz passou a ser acusada de 'denegrir os bons costumes', 'ter vida desregrada', 'ser mulher de vida fácil' etc. Na verdade, era como que o assassino tivesse livrado a sociedade brasileira de um indivíduo que punha em risco a moral da 'família brasileira'. 0 resultado do julgamento de Doca Street provou a eficácia desta lógica junto à Justiça. (Miriam Pillar Grossi, 1993, p. 167).

Mas esse primeiro desfecho também contribuiu para organizar um movimento contra a impunidade de assassinatos de mulheres por homens, sejam

Dossiê Crise, Feminismo e Comunicação - https://revistaecopos.eco.ufrj.br/

ISSN $2175-8689$ - v. 23, n. 3, 2020

DOI: 10.29146/eco-pos.v23i3.27643 
maridos, namorados, amantes, companheiros. Assim se criou a primeira campanha feminista de luta contra a violência doméstica, "Quem ama não mata".12 E, em 1982, a Rede Globo produziu uma minissérie homônima, de 20 capítulos, inspirada em crimes desse tipo ${ }^{13}$, valendo-se da repercussão que essa problemática gerava na sociedade.

Todavia, em enfrentamento ao conservadorismo da sociedade da época, a Globo produziu a emblemática série Malu Mulher que foi veiculada no período de maio de 1979 até dezembro de 1980, no horário das 22 horas. A protagonista era uma "mulher desquitada" que dá os primeiros passos em direção à sua emancipação do mundo privado, mirando à vida pública. Embora no texto de divulgação, a série prometesse "não ter a intenção preestabelecida de mudar o mundo, contestar as estruturas ou fazer a revolução: nem a política, nem a feminista, nem a sexual" (apud Rubim, 2001), estabelecia proximidade com pautas feministas (divórcio, aborto, prazer sexual, entre outros) que ecoavam nas camadas médias urbanas. Também, causando polêmica e contestação na opinião pública, entre 1980 e 1986, o programa TV Mulher (Rede Globo), na grade horária da manhã, veiculou um quadro com Martha Suplicy, que, pela primeira vez, falava em cadeia nacional, sobre comportamento sexual, incluindo orgasmo, menstruação, sexo seguro e temas afins.

Em termos conjunturais, o ano de 1979 marcou o início de uma série de medidas, instituídas pelos militares, que garantiria um processo de transição até a restauração do sistema democrático. Contudo, o período da redemocratização revelou uma continuidade com o estágio anterior, apesar da diferença contrastante da conjuntura política. Isto é, foi um tempo de forte participação política das

\footnotetext{
12 No primeiro julgamento, Doca Street foi condenado a dois anos de prisão, com direito a cumprir a pena em liberdade. Em decorrência da repercussão na sociedade e da ação do movimento feminista, o assassino foi levado a um segundo julgamento, onde foi condenado a quinze anos em regime fechado. 0 assassinato de Ângela Diniz foi recuperado em podcast Praia dos Ossos, da Rádio Novelo, em 8 episódios, sendo o sétimo episódio dedicado à luta feminista, às manifestações que foram organizadas na época e à campanha Quem ama não mata, inclusive, contando como surge esse slogan.

13 Problemática retomada, recentemente, pela série brasileira da Netflix, Coisa mais linda, principalmente, na segunda temporada (2020) quando trata do julgamento do assassino de Ligia, seu marido.
}

Dossiê Crise, Feminismo e Comunicação - https://revistaecopos.eco.ufrj.br/

ISSN $2175-8689$ - v. 23, n. 3, 2020

DOI: 10.29146/eco-pos.v23i3.27643 
feministas, aliadas aos partidos políticos e aos setores progressistas da Igreja em defesa do retorno à democracia. Em consequência, houve conquista de espaço no plano institucional e de direitos na Constituição de 1988 (Pinto, 2003, p. 68-78).

Em termos de estudos feministas, os primeiros núcleos de pesquisa que surgiram nas universidades brasileiras, inspirados em modelos norte-americanos e franceses (Santos, 2016), ganharam expressão no final da década de 1970. Seus interesses estiveram principalmente focados, nos 1980, em torno de questões de saúde, incluindo o aborto, e de violência contra as mulheres (Pinto, 2003). E o debate teórico que predominava tinha como eixo a articulação entre questões de gênero e classe, diferentemente do de suas referências do Norte (Rodrigues, Assis, 2018).

Durante muito tempo, o movimento feminista no Brasil se configurou prioritariamente pelo engajamento de professoras universitárias (da área das ciências sociais, direito, psicologia, letras e história) e profissionais liberais (sobretudo, médicas). Isso teve várias consequências. Para a arrancada inaugural, no que diz respeito às relações entre comunicação e questões de gênero, o viés intelectualizado propiciou o desenvolvimento de um feminismo acadêmico, afinado com o mundo da cultura erudita, mas não com o da cultura popular de massa. Essa característica possivelmente contribuiu para inibir a investigação sobre esta última no âmbito dos estudos feministas, apesar da presença de temas correlatos ao feminismo na mídia, conforme referido anteriormente.

Na trajetória dos estudos de comunicação, em especial nesse estágio mais inicial, tanto em São Paulo quanto no Rio de Janeiro, até então, os dois polos acadêmicos da área, a influência da crítica à indústria cultural, proposta pelos frankfurtianos, promoveu como chave de leitura a reprodução da ideologia. Como corolário dessa perspectiva teórica, em um contexto de autoritarismo político e de dominação econômica, política e cultural do imperialismo norte-americano, os meios de comunicação somente poderiam atuar a favor do capital industrial.14 Logo, o tipo de pesquisa predominante nessa etapa estava fortemente interessada

14 Essa etapa da pesquisa brasileira em comunicação é discutida em maior detalhe em Rüdiger; Escosteguy (2017).

Dossiê Crise, Feminismo e Comunicação - https://revistaecopos.eco.ufrj.br/

ISSN $2175-8689$ - v. 23, n. 3, 2020

DOI: 10.29146/eco-pos.v23i3.27643 
nas ideologias das mensagens e seus efeitos no público investigado.

Ilustra essa posição a pesquisa de Jane Sarques ([1981] 1986). Concentrada no papel que a telenovela exerce ao promover a dominação sexual da mulher dentro do casamento monogâmico, a autora revela a subordinação da mulher "aos interesses econômicos e à reprodução do sistema social da sociedade de classes" (1986, p. 195). Embora se identifiquem diferenças nas leituras das mensagens entre as mulheres pesquisadas - domésticas e donas de casa -, de acordo com os interesses das respectivas classes, seu sentido converge "[n]a reprodução da ideologia que alicerça a estrutura de dominação que as oprime e discrimina" (Sarques, 1986, p. 199).

Quase uma década distancia a investigação de Eclea Bosi da de Jane Sarques. Porém, a de Eclea Bosi, comentada antes, não adere as mesmas premissas do estudo de Jane Sarques. Daí seu pioneirismo e originalidade, diante de um exíguo conjunto de investigações, realizado nos anos 1980, que vai dar atenção às receptoras, mas aderir à uma visão esquemática e mecânica sobre a recepção das mensagens dos meios com a qual Jane Sarques compartilha.

Outro trabalho dessa arrancada inaugural que lança mão da categoria mulher, é o estudo realizado por Dulcília Buitoni, Mulher de papel (1981). Na primeira edição, percorre noventa anos de imprensa feminina brasileira, de 1880 a 1970. Nas palavras de Eclea Bosi ([1981] 2009, p.17), que faz o prefácio da obra, "Dulcília procedeu na linha de uma apreensão de múltiplos significados que se reportassem à condição feminina, espelhada ou idealizada nas revistas e nos jornais para mulheres que estudou". Certamente, o foco nas revistas femininas vincula-se a uma preocupação, explorada pioneiramente por Betty Friedan, com a maneira com que as mulheres são retratadas nesses textos.

No entanto, os resultados obtidos por Dulcília Buitoni não se alinham com uma pluralidade de sentidos, conforme destacado por Eclea, ao contrário. Ao procurar os significados do conceito mulher o que a autora encontra nas revistas são modelos e estereótipos, imposição de normas de comportamento e prescrição de atitudes, enfim, uma ideologia que reproduz papéis tradicionais de gênero. Além disso, a indagação que lança logo no início do estudo - "Existe mulher de 
verdade nas revistas femininas?", bem como o próprio título da obra marcam o que há de mais problemático nesse enfoque: a relação entre mídia e realidade.

$\mathrm{Na}$ perspectiva acionada nessa pesquisa, toma-se como ponto de partida a existência de dois elementos separados: a entidade "real" da mulher e a imagem “irreal”, produzida pela mídia, isto é, sua representação falsa ou distorcida. Assim, entende-se que as "imagens de mulher", postas em circulação pela mídia, deveriam ser reflexo da sociedade. Daí o desalento conclusivo de Dulcília: "faltavam mulheres de verdade nas páginas femininas". Resultado reiterado, na segunda edição desse estudo, publicada em 2009, quando a autora inclui as décadas de 1980 e 1990.

Esse entendimento permanece vigente nos estudos de mídia até os dias de hoje, apesar de sua simplificação. Contudo, a discussão tem avançado para a compreensão de que "os meios de comunicação não representam bem ou mal as identidades de gênero, mas trabalham para construir e estruturar seu significado" (Hollows, 2005, p. 18). Consequentemente, os meios estão implicados na definição da realidade e na construção de representações das mulheres e de outras identidades de gênero e de sexualidade. Sendo assim, a mídia participa, de modo ativo, da construção do que significa ser mulher, entre outros modos de ser, num contexto histórico específico, produzindo até mesmo sentidos contraditórios.

Em síntese, no início das relações entre Comunicação e questões de gênero, observa-se que a combinação de fatores - por um lado, as particularidades da conjuntura sociopolítica brasileira e da formação do nosso movimento feminista e, por outro, as perspectivas teóricas predominantes nos estudos de comunicação desse período (1970/1980) - é causa para o tardio deslanchar de uma análise cultural interessada nas questões de gênero, no contexto universitário-acadêmico da Comunicação.

Dossiê Crise, Feminismo e Comunicação - https://revistaecopos.eco.ufrj.br/

ISSN $2175-8689$ - v. 23, n. 3, 2020

DOI: 10.29146/eco-pos.v23i3.27643 


\section{Anos 1990: gênero, mera etiqueta}

Ao mesmo tempo que o feminismo se popularizou, no Norte, nos anos 1990, a mídia nacional foi porta voz do prenúncio de sua derrota no Brasil. No dia 8 de março de 1992, por exemplo, o suplemento cultural da Folha de S. Paulo, Mais!, estampou em sua capa: "O feminismo abre as pernas". Essa tomada de posição propagandeava seu fim via um "bota-abaixo da cultura da esquerda, dos movimentos sociais, suas lutas e conquistas" (Schmidt, 2000, p. 80), em um contexto pós queda do Muro de Berlim, de fim do tempo de bandeiras políticas e utopias e ascensão do neoliberalismo com sua respectiva defesa das liberdades individuais e combate às lutas sociais.

Em análise do contexto nacional, observou-se que

Se, por um lado, a década de 90 não foi especialmente propícia à expansão dos movimentos sociais, havendo mesmo um retraimento da maioria deles, por outro nela foram criadas as condições para que suas demandas [do feminismo] fossem incorporadas por largas parcelas dos discursos públicos. (Pinto, 2003, p. 92).

Portanto, identificaram-se avanços nas relações de trabalho onde se tornou mais difícil a discriminação por sexo, aprovaram-se políticas públicas de reconhecimento da mulher como vítima da violência - embora esta não tenha declinado -, cresceu o interesse e aumentou a visibilidade de questões referentes aos direitos da mulher em campanhas eleitorais, bem como despontou a discussão sobre assédio sexual, entre outras manifestações. Em termos de conjuntura vivida, segundo a mesma cientista política, vivenciou-se um "feminismo difuso", ainda que não se identificasse a organização orquestrada de demandas, nem a militância pelo feminismo. Até mesmo porque homens e mulheres que defendiam esses direitos não se autoproclamavam feministas nem militantes de um movimento feminista (Schmidt, 2000).

Conjugado com esse clima de "guerra fria contra o feminismo" travada por jornais nacionais de grande tiragem (Schmidt, 2000), destaca-se, em contrapartida,

Dossiê Crise, Feminismo e Comunicação - https://revistaecopos.eco.ufrj.br/

ISSN $2175-8689$ - v. 23, n. 3, 2020

DOI: 10.29146/eco-pos.v23i3.27643 
a circulação do seriado Mulher ${ }^{15}$, entre abril de 1998 e dezembro de 1999, produzido pela Globo, onde as duas protagonistas da narrativa tentavam compatibilizar a vida privada e a pública, esta última retratada como "já conquistada" pela presença das mulheres no mercado de trabalho. No caso dessa produção televisiva, tratava-se de duas mulheres plenamente realizadas profissionalmente num campo de atuação que tinha sido reconhecido prioritariamente como masculino - a medicina. Contudo, alguns episódios reafirmam a culpa e o sacrifício como horizontes impostos à nova condição feminina, no que diz respeito ao mundo da vida privada (Rubim, 2001). Ou seja, há no seriado um discurso contraditório sobre a emancipação das mulheres, atravessado por valores de um individualismo vinculado à uma retórica neoliberal onde se privilegia a liberdade de escolha e o empoderamento individual.

Já no contexto internacional ao longo da década de 90, consolidou-se uma perspectiva teórica que examina uma variedade de elementos na constituição da condição feminina. Ao reivindicar que o gênero institui a identidade do sujeito, assim como a classe, "a unidade do feminismo, construído pelo discurso de opressão comum das mulheres nas sociedades patriarcais, é contestada". Esse posicionamento vai se constituindo no final dos anos 1980 e "inaugura uma noção de múltiplas opressões, notadamente aquela que emerge das desigualdades raciais. Ao discurso binário simples que opunha mulheres e homens sobrepõem-se outras oposições binárias, sobretudo entre mulheres brancas e negras, do Sul e do Norte" (Gomes, Sorj, 2014, p. 435).

Nesse sentido, há o reconhecimento de que qualquer ponto de vista feminista obrigatoriamente deve levar em conta que, embora as mulheres possam compartilhar interesses comuns, esses não são universais. Tal posicionamento se opõe àquele discurso feminista que até um determinado momento apelava para a opressão comum sofrida pelas mulheres, existindo um chamado pela unidade que apagava as diferenças entre elas.

15 Ver detalhes da produção, roteiro, trama em https://memoriaglobo.globo.com/entretenimento/series/mulher/bastidores/Acesso em 22 de outubro de 2020.

Dossiê Crise, Feminismo e Comunicação - https://revistaecopos.eco.ufrj.br/ ISSN $2175-8689$ - v. 23, n. 3, 2020

DOI: 10.29146/eco-pos.v23i3.27643 
Sendo assim, a análise vai se desprender de uma ideia reduzida de construção social de papéis/funções do feminino e do masculino para uma abordagem muito mais multifacetada que redimensiona as supostas diferenças/identidades entre mulheres e homens. É no bojo de revisões sobre as primeiras formulações do conceito de gênero que se dá a busca por categorias analíticas alternativas que considerem conjuntamente diversos marcadores sociais. Entre as que adquirem proeminência a partir do feminismo negro está a proposição de interseccionalidade, de Kimberlé Crenshaw, sistematizada conceitualmente na década de 1990.

Ainda no contexto do Norte, no âmbito das relações entre comunicação e questões de gênero, nota-se que os objetos de estudo vão se transformando: de uma preocupação mais centrada em questões de ideologia para a atenção à problemática das identidades e aos estudos de recepção que privilegiavam um tratamento mais focalizado nos modos pelos quais os sentidos são recebidos e vividos por determinados grupos sociais.

Porém, no Brasil, no espaço da comunicação, no período do segundo impulso, anos 1990, ainda não há um engajamento teórico com questões que envolvam cruzamentos entre gênero, raça e classe, ainda que já existissem contribuições sobre o tema, como mostra a produção de Lélia Gonzalez e Sueli Carneiro. Assim, observam-se mais continuidades do que rupturas com os anos 1980. Por um lado, permanece evidente nas pesquisas a concentração nas mensagens midiáticas e, teoricamente, o viés da ideologia (Escosteguy, Messa, 2008). Em consequência, não se produz o abandono de abordagens esquemáticas, vigentes entre 1970-1980. Por outro, os desvios são ainda muito tímidos. Por exemplo, aparecem, pontualmente, como objeto de estudo, as experiências feministas em vídeo, o interesse pelo masculino, pelas mulheres negras e indígenas e, especialmente, nota-se a emergência dos estudos de recepção.

Em análise de produção acadêmica sobre a recepção, da década de 1990, observo (Escosteguy, 2002) que, embora exista um destaque às mulheres como informantes, a problemática de gênero não fazia parte do eixo estruturador da pesquisa. Esse mesmo resultado foi referendado por Nilda Jacks (2008). Também,

Dossiê Crise, Feminismo e Comunicação - https://revistaecopos.eco.ufri.br/

ISSN $2175-8689$ - v. 23, n. 3, 2020

DOI: 10.29146/eco-pos.v23i3.27643 
foi constatado que o termo gênero, no corpus analisado (Escosteguy, 2002), era fundamentalmente usado como sinônimo de "mulher" e apenas para indicar uma distinção sexual entre feminino e masculino, portanto, atravessado por essencialismos.

Para Nilda Jacks (2008, p. 199), a preferência pelas amostragens femininas, nos estudos de recepção, "parece [indicar] que a opção por investigar mulheres foi uma decisão prática, porque muitas são donas de casa, mais facilmente encontradas e com mais tempo disponível". Todavia, a autora faz referência a duas exceções: uma pesquisa sobre a recepção de romances populares e outra sobre a recepção de telenovela por camponesas, onde ambas "procuram fazer certa articulação da condição feminina com a estruturação social, ainda que, por vezes, de maneira limitada."

Esta última pesquisa, intitulada "Cotidiano rural e recepção de televisão: o caso de Três Barras" (Dissertação de Mestrado ECA/USP, 1993), ganha repercussão na vertente dos estudos de recepção, via a trajetória de sua autora, Veneza Mayora Ronsini (UFSM). Explorando pioneiramente uma articulação entre os marcadores de classe social e gênero, esse enfoque vai adquirir força em várias de suas orientações de mestrado e doutorado a partir de meados dos anos 2000.

Ainda, na década de 1990, aflora uma forte crítica ao feminismo brasileiro, em relação ao seu caráter de classe média, branco, intelectualizado e heterossexual (Pinto, 2003). Porém, no Norte, em uma tendência de crítica à heteronormatividade e aos binarismos de gênero e sexualidade, especificamente, no contexto social dos Estados Unidos, emerge, no início dessa mesma década, a produção de um novo olhar sobre o binômio sexo/gênero via a teoria queer. ${ }^{16}$ Todavia, no Brasil, a incorporação dessa perspectiva se deu apenas no final dos anos 1990, possivelmente em decorrência do forte traço heterossexual do feminismo da época. Além disso, ela se deu no âmbito das disciplinas das Ciências Sociais, constituindo-se em "marco de nossa recepção queer", segundo Richard

${ }^{16}$ As "lentes queer ", segundo Fernando Benetti (2013), estão associadas ao contexto vivido no final dos anos 1980, nos Estados Unidos, e ao surgimento da AIDS. Contudo, a nomeação Teoria Queer aparece pela primeira vez em artigo de Teresa de Lauretis, publicado na revista Differences, em 1991.

Dossiê Crise, Feminismo e Comunicação - https://revistaecopos.eco.ufrj.br/

ISSN $2175-8689$ - v. 23, n. 3, 2020

DOI: 10.29146/eco-pos.v23i3.27643 
Miskolci (apud Benetti, 2013, p. 25), artigo de Guacira Lopes Louro, publicado em 2001, na Revista de Estudos Feministas. ${ }^{17}$

Embora a apropriação dessa abordagem na comunicação mereça uma revisão atenta e específica - importante lembrar que isso não faz parte da discussão proposta aqui -, provavelmente, um dos primeiros pesquisadores da comunicação a tomar contato com ela tenha sido Denilson Lopes ${ }^{18}$, em meados dos anos 1990, quando realizava seu doutorado-sanduíche na City University of New York. Em depoimento, reconhece que "foi decisivo ler os autores associados à queer theory", em 1995/1996; apesar disso, no seu retorno ao Brasil, não pretendeu tornar-se "um divulgador da Teoria Queer, como se fosse uma reprodução colonizada de autores, ideias e modismos" (apud Benetti, 2013, p. 70). Logo, suas primeiras produções sobre o tema, escritas a partir de 1997, apenas perpassam os estudos queer.

Considerando o que foi dito sobre a circulação dessa perspectiva no contexto acadêmico nacional, os estudos de viés queer na comunicação são inexistentes ao longo do segundo impulso - anos $1990 .{ }^{19}$ De todo modo, eles vão contribuir, ao longo do tempo, para assumir um sujeito político, vinculado aos feminismos, mais diversificado e multifacetado, incluindo a compreensão de identidades LGBTQI+.

\footnotetext{
${ }^{17}$ Fernando Benetti $(2013$, p.56) tem uma visão mais modulada sobre a recepção da teoria queer no Brasil. Identifica um primeiro momento de emergência das "lentes queer" no final dos anos 1970 e ao longo dos 1980; um segundo movimento, que ocorre nos anos 1990, onde diversos pesquisadores/as entram "em contato" com a Teoria Queer; e o desenvolvimento dos Estudos Queer a partir dos anos 2000.

${ }^{18} \mathrm{Na}$ época, atuava na UnB; hoje, na UFRJ.

${ }^{19}$ Em recente análise da trajetória da vertente de estudos de viés queer, trans, gays e lésbicos na comunicação, em teses e dissertações da área da comunicação, no período de 1972 até 2015, Tainan Tomazetti (2019) observou: a) antes de 1990 não foi possível localizar nenhum trabalho atravessado por essa temática; b) ao longo da década de 1990, quatro pesquisas tangenciam temas vinculados à homossexualidade masculina, sendo que duas foram realizadas no ano de 2000; c) é somente em 2004 que a abordagem queer ingressa na comunicação, via a dissertação de Sofia Cavalcanti Zanforlin, Nem comédia, nem drama: Gay como gente. Análise crítica do seriado televisivo Os Assumidos (Queer as Folk) (UnB) e a tese Comunicação, sociabilidade e escrita de si: A comunidade GLS no ciberespaço (UFBA), de Gisele Marchiori Nussbaumer.
}

Dossiê Crise, Feminismo e Comunicação - https://revistaecopos.eco.ufrj.br/

ISSN 2175-8689 - v. 23, n. 3, 2020

DOI: 10.29146/eco-pos.v23i3.27643 


\section{Virada do século: a ascensão do pós-feminismo}

A virada do milênio, bem como a década de 1990, como recém apontado, permaneceu acompanhada por persistentes evocações sobre a morte e o fim do feminismo. Tanto a mídia quanto textos acadêmicos vaticinaram que o feminismo era coisa do passado. Porém, quase no final do primeiro decênio do século XXI, a declaração de Contardo Calligaris, psicanalista e colunista da Folha de São Paulo, em 5/11/2009, sobre o caso Geise Arruda ${ }^{20}$ e "a turba da Uniban" revelou a cilada desse vaticínio:

devo desculpas a todas as mulheres que militam ou militaram no feminismo. Ainda recentemente, pensei (e disse, numa entrevista) que, ao meu ver, o feminismo tinha chegado ao fim de sua tarefa histórica. Em particular, eu acreditava que, depois de 40 anos de luta feminista, ao menos um objetivo tivesse sido atingido: o reconhecimento pelos homens de que as mulheres (também) desejam. Pois é, os fatos provam que eu estava errado (Calligaris, Folha de S. Paulo, 5/11/2009)

Aqui não interessa fazer uma autópsia dessa morte anunciada, em tempos de vozerio teórico e militante, revelador, sobretudo, do seu vigor e do florescer de uma pluralidade de posições. Apenas aventar que uma possível causa do réquiem é a força centrífuga que se constituiu internamente ao próprio feminismo. Ao invés de agir unitariamente por mudanças sociais, o movimento se estilhaçou. A recusa do universalismo e a adoção de um arsenal teórico em favor de uma "política da diferença" escancarou complexos desafios para a prática política e cindiu o feminismo contemporâneo "entre as defensoras da identidade e as partidárias da(s) diferença(s)" (Richard, 2002, p. 157). Um dilema, em processo, para a prática política feminista contemporânea. Também, fragmentada devido às três dimensões - econômica, política e cultural - abarcadas por suas distintas pautas.

A outra causa de sua possível despotencialização desfraldou a bandeira, à moda de tese darwiniana, de evolução do feminismo à consagração do pósfeminismo. Ataque mais sutil porque pressupõe que as lutas feministas são ultrapassadas e, portanto, não há mais razão para sua existência. Desse ponto de

20 Jovem, estudante universitária, que no dia 22 de outubro de 2009, foi vítima de assédio dentro do recinto de uma universidade privada, na cidade de São Paulo.

Dossiê Crise, Feminismo e Comunicação - https://revistaecopos.eco.ufrj.br/

ISSN $2175-8689$ - v. 23, n. 3, 2020

DOI: 10.29146/eco-pos.v23i3.27643 
vista, o feminismo pareceu algo datado, que não tinha mais função. No seu lugar, viria algo mais avançado.

De todo modo, a natureza do pós-feminismo tem sido tema de considerável disputa e controvérsia teórica. Tanto existem versões de que o pós-feminismo sugere um processo evolucionário, quanto um "novo consenso" que une distintos grupos em prol de um retorno a valores familiares tradicionais. Ou seja, há teses que circulam nas fileiras feministas e outras, em círculos conservadores.

Todas essas controvérsias repercutem, também, no âmbito acadêmico. Apesar das dificuldades em estabelecer uma periodização, penso que um terceiro impulso nas relações entre Comunicação e questões de gênero se constitui na virada de século até 2015 , marcado pela crítica ao pós-feminismo. E é no início desse período em que minha afinidade com esse tema toma forma.

Inicialmente, realizo um levantamento bibliográfico sobre as intersecções entre estudos culturais, estudos de recepção e feminismo, publicado sob o incompleto título "A contribuição do olhar feminista" (Escosteguy, 1998). 0 complemento que lhe falta diz respeito à sua delimitação espacial, isto é, o artigo pretende dar conta dos aportes feministas aos estudos culturais britânicos. Logo após o doutoramento, proponho o projeto de pesquisa, Os Estudos Culturais e a problemática da recepção: A categoria gênero em debate ${ }^{21}$ (CNPq 2001-2003), com o qual me transformei em pesquisadora do CNPq (Conselho Nacional de Desenvolvimento Científico e Tecnológico).

Nesse período, consolida-se o desdobramento de duas frentes de pesquisa que já estavam em gestação desde os anos 1970. Uma continua mais centrada nas práticas de ver, ler, consumir e usar a mídia, dando continuidade ao objetivo de compreender os efeitos dos sentidos, postos em circulação pela mídia. Contudo, essa problemática, a partir dos anos 1990, fortalece um entendimento das práticas com a mídia como um processo de negociação. A outra foca mais em questões de textualidades e representações midiáticas. Contemplando esses dois enfoques,

21 Se, em um primeiro momento, meu olhar esteve ancorado na descoberta exclusivamente de autoras situadas na Europa, na sequência, preferi cruzar a fronteira de retorno ao espaço nacional e latino-americano para recuperar e reconstituir o trajeto "daqui", com o objetivo de refletir sobre suas especificidades. Este texto faz parte dessa guinada.

Dossiê Crise, Feminismo e Comunicação - https://revistaecopos.eco.ufrj.br/

ISSN $2175-8689$ - v. 23, n. 3, 2020

DOI: 10.29146/eco-pos.v23i3.27643 
reuni parte de uma produção de alunas da graduação e pós-graduação em Comunicação e gênero: a aventura da pesquisa (Escosteguy et alii, 2008). ${ }^{22}$

Sobre os estudos de recepção que se interseccionam com relações de gênero, do período 2000 a 2009, Lourdes Silva e Valquíria John (2016, s/p) observam que "aparentemente continua-se a trabalhar em um modelo binarista". Mesmo assim, nota-se no levantamento realizado pelas autoras um despontar para um novo interesse: a homossexualidade feminina a partir da recepção da telenovela. E, em direção contrária do período anterior, as duas pesquisas que assumem esse objeto de estudo, "evidenciam aprofundada discussão sobre sexualidade e papeis de gênero a ela relacionados" (Idem), ao invés da fraca discussão teórica dos anteriores. Além disso, uma delas assume a perspectiva queer $^{23}$, outra novidade desta fase.

A outra frente, de caráter mais textualista, está interessada nas representações que circulam pela mídia, ora marcadas pelo contexto do pósfeminismo, ora pelo reconhecimento de identidades LGBTs. Em ambos os desdobramentos entende-se o espaço midiático como uma arena de disputa simbólica. Esse enquadramento teórico foi encontrado em um exíguo conjunto de artigos, publicado nos principais periódicos feministas, Cadernos Pagu e Revista Estudos Feministas, no período de 2001 a 2009. Ou seja, “a mídia se apresenta nesses artigos como meio de construção, desconstrução e reconstrução das noções de gênero, corpo e sexualidade", dizem Lírian Sifuentes, Bruna Silveira e Janaína Oliveira (2012, p. 196). ${ }^{24}$ Contudo, o tema não adquire nenhuma repercussão no

22 Reitero que esta narrativa das relações entre comunicação e gênero está fundamentalmente baseada na minha condição de pesquisadora. Portanto, o relato prioriza pesquisas que estão vinculadas com minha experiência, sendo assumidamente parcial e incompleto. Destaco algumas das primeiras monografias que versavam sobre o tema, embora nem todas façam parte da coletânea: de Mariana Pires, As identidades de gênero na mídia: o caso da revista VIP (FAMECOS/PUCRS, 2003); de Cristina Vanuzzi, Da submissão ao Girl Power: gênero e sexualidade na revista Capricho (FAMECOS/PUCRS, 2004); de Bruna Gandolfo, Seja diferente, seja você: Produção de sentido, identidade e adolescência nas capas de Capricho, Atrevida e Todateen (FAMECOS/PUCRS, 2006).

${ }^{23}$ A referência é Sílvia Gomide, Representações das identidades lésbicas na telenovela Senhora do Destino. Dissertação de Mestrado, UnB, 2006.

${ }^{24} \mathrm{Na}$ época, eram minhas orientandas, participavam do grupo de pesquisa por mim coordenado e realizavam suas pesquisas sobre temas correlatos.

Dossiê Crise, Feminismo e Comunicação - https://revistaecopos.eco.ufrj.br/

ISSN $2175-8689$ - v. 23, n. 3, 2020

DOI: 10.29146/eco-pos.v23i3.27643 
elenco temático dessas publicações na década analisada: apenas $4,8 \%$ do total de artigos trata disso.

A temática das identidades LGBTs é embrionária na primeira década deste século. Referenda esse argumento o levantamento e análise realizado por Fernanda Nascimento ${ }^{25}$ (2015) que identifica a realização da primeira pesquisa acadêmica sobre personagens LGBTs na telenovela brasileira em 2002, embora sua participação nas narrativas date de 1970. Esse levantamento abarcou tanto estudos centrados no texto quanto na recepção e seus resultados corroboram a existência de um único estudo que adotou a perspectiva queer na realização de pesquisa de recepção de telenovela, sendo "o primeiro trabalho na qual a especificidade do gênero feminino dentro da homossexualidade é apresentado de forma mais profunda" (Silva, 2015, p. 242).

Outra articulação parcamente explorada na primeira década dos 2000 é a da pesquisa em jornalismo e questões de gênero. Em levantamento e análise dos trabalhos apresentados desde o primeiro encontro (2003) da Associação Brasileira de Pesquisadores em Jornalismo (SBPJor) até 2014, Monica Martinez, Claudia Lago e Mara Lago (2016) definem essa relação como "tênue" já que foram identificados apenas sete trabalhos. Incluído nesse conjunto está "Masculino, o gênero do jornalismo: um estudo sobre os modos de produção das notícias", fruto da dissertação de mestrado de Márcia Veiga (2010), posteriormente, publicada em livro (2014). Trata-se de marco importante que inaugura o uso da categoria de gênero na pesquisa em jornalismo, transformando-se em ponto de partida para estudos subsequentes.

No que diz respeito ao pós-feminismo, ressalta-se sobretudo a incorporação do entendimento de Angela McRobbie (2006). Para a autora, a cultura midiática, através desse rótulo, efetiva um apagamento do feminismo - de sua luta, de sua história, quando dissemina a ideia de que é algo datado e não tem mais função.

25 Fernanda inicia sua trajetória realizando a monografia de conclusão do curso de Jornalismo, Homoafetividade e identidade gay: representações na teledramaturgia (PUCRS, 2011). Também, sob minha orientação, realiza seu mestrado (2015). E conclui seu doutoramento, Sapatões e mídia: Produções de identidades a partir de práticas de recepção, em 2020, no Programa de Pós-Graduação Interdisciplinar em Ciências Humanas, UFSC.

Dossiê Crise, Feminismo e Comunicação - https://revistaecopos.eco.ufrj.br/

ISSN $2175-8689$ - v. 23, n. 3, 2020

DOI: 10.29146/eco-pos.v23i3.27643 
Através de textos prazerosos e bem-humorados (filmes, seriados de TV, anúncios publicitários, etc) que contraditoriamente tanto se filiam a valores neoconservadores em relação ao gênero quanto se integram a processos de caráter mais liberador, as relações de poder são feitas e refeitas, construindo um "novo regime de gênero" que visa regular os modos de ser através do discurso da escolha própria ou do direito de escolha. Nesse contexto, as conquistas femininas são apresentadas como fruto de trajetórias individuais e não, do movimento feminista e dos embates estabelecidos no seu percurso.

0 artigo "Pós-feminismo e cultura popular: Bridget Jones e o novo regime de gênero" (McRobbie, 2006), em tradução de Márcia Messa, minha orientanda na época, foi um dos difusores dessa compreensão. ${ }^{26}$ Apropriando-se desse referencial, sua dissertação de mestrado, As mulheres só querem ser salvas: Sex and the City e o pós-feminismo (2006, p. 23), analisa essa série do ponto de vista de sua produção, seu texto e sua recepção, definindo-o como um programa de televisão pós-feminista que coloca a mulher não só como capaz de ganhar sua própria vida, mas como suficientemente autoconfiante para assumir que tem medo de não casar e de não ter filhos “Mas o mais relevante neste seu processo de 'evolução' é que ela [a mulher] é confiante o suficiente para não ter vergonha de admitir isso."

Assumindo esse mesmo viés crítico ao pós-feminismo, outras jovens pesquisadoras como Lígia Lana, Tatiane Leal, entre outras, têm se dedicado também a explorar essa perspectiva. Essas análises estão centradas em identificar a mídia como um local de produção e de construção da subjetividade feminina relacionada diretamente com ideais tradicionais de feminilidade e a construção de um modelo identitário de uma "nova mulher", geralmente bem-sucedida e poderosa. Como nos diz Tatiane Leal (2015, p. 56): "A poderosa representa um backlash ao negar a necessidade de mudanças estruturais e aproxima-se das concepções pós-feministas centradas no empoderamento, ao invocar um tipo de

\footnotetext{
${ }^{26}$ É imperativo mencionar a forte atuação de João Freire Filho (UFRJ) em temas afins, a partir dos anos 2000, quando desenvolveu uma pesquisa pioneira sobre as revistas femininas juvenis e, também, com uma série de orientações e supervisões de pós-graduação. Entre os primeiros estudos sobre o tema, destaco 'Seja diferente. Seja você': Romantismo, pós-feminismo e consumismo nas páginas da revista Capricho. Logos, 12 (1), 2005.
}

Dossiê Crise, Feminismo e Comunicação - https://revistaecopos.eco.ufrj.br/

ISSN $2175-8689$ - v. 23, n. 3, 2020

DOI: 10.29146/eco-pos.v23i3.27643 
feminismo que busca ser menos um movimento teórico-social do que uma convocação individual a uma revolução interior".

Portanto, as representações da "mulher poderosa" convocam as mulheres mais para uma transformação individual do que para a ação política. Nessa direção, entende-se que há uma ressignificação da agenda feminista e sua utilização pelo discurso neoliberal. A vigência dessa problemática entre nós e, também, no contexto anglo-americano, marca pela primeira vez uma certa reciprocidade entre os desdobramentos dos nossos estudos de mídia no Sul e aqueles desenvolvidos no Norte, mostrando sintonia com um feminismo global.

Igualmente em convergência com a reflexão sobre o pós-feminismo, mas associando-a à temática das opressões cruzadas - gênero, raça e classe social, destaco o estudo de Lúcia Coutinho (2010) que analisou o seriado Antônia, veiculado pela Globo, em 2006 e 2007, focado em mulheres negras, pobres e moradoras de uma favela. A autora conclui que a série trabalha em uma articulação entre uma postura conservadora e outra de ruptura. Assim, Antônia promove uma imagem positiva de mulher, dando ênfase à independência, ao orgulho de ser mulher e à autoafirmação da raça, ao mesmo tempo em que mantem reguladas essas diferenças dentro de um modelo que não apresenta risco ao status quo entre homens e mulheres.

A ideia de que existem várias categorias sociais que se sobrepõem, se afetam e são afetadas, entre elas, em situações diversas, tem relativa ocorrência desde os anos 1970, como mostramos. A diferença nesta etapa é que se retoma a investigação dessa alquimia, inicialmente, entre gênero e classe, com mais fluência, rejeitando qualquer hierarquização, depois de um período de resistência ao uso de classe social. ${ }^{27}$

Porém, as intersecções entre gênero e raça ou gênero, classe e raça permanecem muito pouco exploradas. Tânia Montoro e Ceiça Ferreira (2014, p.

${ }^{27}$ Exemplos recentes de pesquisas que usam a categoria classe social: Lírian Sifuentes, Todo mundo fala mal, mas todo mundo vê: estudo comparativo do consumo de telenovela por mulheres de diferentes classes (Tese, Comunicação/PUCRS, 2014); Milena Freire de Oliveira Cruz, Dona de casa e da própria vida? Leituras sobre o trabalho feminino na publicidade por mulheres da nova classe trabalhadora (Tese, Comunicação/UFSM, 2016). A primeira, sob minha orientação; a segunda, por Veneza Mayora Ronsini.

Dossiê Crise, Feminismo e Comunicação - https://revistaecopos.eco.ufri.br/

ISSN $2175-8689$ - v. 23, n. 3, 2020

DOI: 10.29146/eco-pos.v23i3.27643 
16), em análise da publicação de artigos científicos, no período de 2000 a 2013, avaliam que a problematização sobre gênero e raça tem "representatividade limitada" no âmbito da pesquisa em comunicação audiovisual e, também, é "timidamente contemplada" nos estudos de recepção. Além disso, reafirma-se a continuidade desse quase silêncio sobre as mesmas intersecções se o foco estiver no cinema (Ferreira, 2017).

Ainda está por ser feita uma análise e sistematização das pesquisas em comunicação que tratam das opressões cruzadas, sobretudo, gênero e raça, ou seja, uma genealogia de como se desenvolveu, em qual contexto e quando ocorreu a emergência dessa problemática no Brasil, bem como quais seus vieses teóricos. Por essa razão, reitero que este relato está fundamentalmente baseado na minha condição de pesquisadora, priorizando investigações que estão vinculadas a esse percurso. Sendo assim, as conclusões que seguem sobre o tema, são parciais, provisórias e até mesmo limitadas, em decorrência dessas vivências, sendo necessário que sejam corroboradas com outras fontes e de modo sistemático.

Enfim, no período que denomino de terceiro impulso, 2001-2015, há escassez de estudos sobre as intersecções entre gênero, classe e raça na comunicação, no contexto acadêmico nacional. ${ }^{28} \mathrm{Se}$, no início do novo milênio, deve-se registrar a ascensão e visibilidade do feminismo negro como prática política no contexto nacional, ele vai adquirindo difusão teórica na comunicação, paulatinamente. ${ }^{29}$

${ }^{28}$ Embora os propósitos e a metodologia assumida na construção desta análise já tenham sido explicitados, reforço que as menções às monografias de graduação, dissertações de mestrado e teses de doutorado levam em conta, principalmente, minha trajetória. No meu itinerário de orientações, destaco uma única orientanda de graduação, Esther Scotti, que explorou a conexão gênero/raça, investigando o consumo televisivo junto a mulheres negras, em $O$ espelho invisível: $u m$ estudo sobre o não-reconhecimento das mulheres negras na televisão brasileira (TCC, FAMECOS/PUCRS, 2006). Recentemente, outra orientanda, Simone Munir Dahleh (2020), em Feminismo(s) midiático(s): apropriações de mulheres a partir do programa televisivo Amor \& Sexo (Dissertação de Mestrado, Comunicação/UFSM), também, tratou do assunto. Embora o título não informe, a investigação foi realizada junto a mulheres brancas e pretas.

${ }^{29} \mathrm{Um}$ fator que pode estar contribuindo para tal é que ações afirmativas como a lei que assegura reserva de vagas para alunas/os egressas de escolas públicas, com renda per capta igual ou inferior a 1,5 salário-mínimo e a alunas/os autodeclaradas pretas, pardas e indígenas é de 2012. Outro dado que tem impacto no ritmo da apropriação dessa temática na academia é que, em 2016, o Censo da Educação Superior identificou que mulheres pretas e pardas com doutorado não chegavam a 3\% do total de docentes do país. Ver

Dossiê Crise, Feminismo e Comunicação - https://revistaecopos.eco.ufrj.br/

ISSN $2175-8689$ - v. 23, n. 3, 2020

DOI: 10.29146/eco-pos.v23i3.27643 
Pensar sobre a recepção da abordagem da interseccionalidade é um recurso para avaliar o andamento da pesquisa sobre questões de gênero/raça na comunicação. Em recente panorama dos estudos sobre interseccionalidade no Brasil publicados no Banco de Teses e Dissertações da CAPES entre 2008-2018, Guilherme Libardi (2019) identificou 26 pesquisas, sendo que 19 delas foram realizadas entre 2015-2018. Além disso, observou que somente quatro tratam de um fenômeno e/ou objeto comunicacional articulado à interseccionalidade. Porém, o indicador mais expressivo é que apenas uma delas foi realizada em programa de pós-graduação em comunicação, em 2018.

De outra parte, também, é ilustrativo explorar em que momento essa mesma problemática - a interseccionalidade - torna-se centro de atenção no percurso intelectual de pesquisadoras da comunicação, vinculadas com a questão racial negra. ${ }^{30}$ Embora não tenha realizado uma análise abrangente e circunstanciada, observei a presença, em separado, ora do enfoque nas relações raciais já existente nos anos 1990, ora o de gênero, mais visível a partir de meados dos anos 2000. Entretanto, a articulação cruzada de gênero e questões raciais ganha relevância a partir de 2018. ${ }^{31}$ Assim, esse conceito/abordagem da

https://www.redebrasilatual.com.br/cidadania/2020/07/cientistas-negras-sao-as-maisafetadas-na-atividade-academica-durante-a-pandemia/

30 Com o objetivo de ampliar meu olhar sobre essa questão, faço uma exploração nas produções intelectuais de pesquisadoras da comunicação que têm publicado atualmente a respeito. Fiz consulta ao Lattes e, principalmente, de títulos de produções intelectuais. Além disso, as pesquisadoras citadas são apenas algumas das que no contexto nacional estão hoje engajadas com a discussão sobre interseccionalidade. Portanto, não se trata de análise metódica nem sistemática.

31 Por exemplo, no itinerário de Dione Moura (UnB), em 1990, sua dissertação de mestrado versava sobre cineastas negros brasileiros, contudo, a centralidade nas questões de gênero vinculada ao tema racial se formaliza a partir de 2018 em sua produção intelectual. No caso de Laura Guimarães Correa (UFMG), a análise dos corpos negros na publicidade impressa brasileira, tema de sua dissertação, intitulada $O$ corpo presente: o negro na publicidade em revista (2006), abrange tanto os corpos femininos quanto os masculinos. Apesar disso, a ênfase está posta nas representações das relações raciais. Ainda focada na publicidade, na sua tese de doutoramento (2011) sobressai o viés de gênero, pois seu olhar está atento aos papeis sociais de pais e mães. As questões raciais vinculadas ao gênero emergem inicialmente em um artigo, publicado em 2011, mas ganham maior proeminência a partir de 2018. Também, a partir desse momento, Fernanda Carrera produz potente discussão sobre a interseccionalidade, culminando com a publicação do artigo Roleta interseccional: proposta metodológica para análises em Comunicação, na revista E-Compós, 2020. Além disso, destaca-se o seminário Comunicação, Interseccionalidade e a Promoção da Igualdade Étnico-racial, realizado em 2019 e, recentemente, o dossiê que tem origem nessa atividade, publicado na revista Esferas (n. 18, 2020).

Dossiê Crise, Feminismo e Comunicação - https://revistaecopos.eco.ufrj.br/

ISSN $2175-8689$ - v. 23, n. 3, 2020

DOI: 10.29146/eco-pos.v23i3.27643 
interseccionalidade repercute na comunicação há bem pouco tempo e vai ser mais notada no próximo impulso.

\section{Entre a primavera feminista e a contraofensiva de um conservadorismo radical}

As periodizações são sempre arriscadas, pois implicam o recorte do tempo com base em acontecimentos marcantes. Assim, entendo a dificuldade em estabelecer marcos que indiquem a configuração dos impulsos nas relações entre os estudos de Comunicação e questões de gênero. Contudo, creio que é pertinente pensar em 2015 como mais um divisor. Embora o termo tenha sido cunhado pela mídia, a "primavera das mulheres" que emergiu nesse ano, congregou uma série de mobilizações que tiveram como elo, para além da defesa de reivindicações históricas do movimento feminista e LGBTQI+, a utilização do espaço da internet como potencializador de inúmeras ações feministas, com destaque para o movimento de mulheres negras e jovens. ${ }^{32}$ Essa é uma novidade o que dá legitimidade para tomar esse ano como uma baliza.

De outra parte, ao considerar a pesquisa acadêmica em comunicação, do período de 2010-2015, que se interessa pela temática do feminismo, é possível extrair outro indicador para justificar essa demarcação. Nesse período, as teses e/ou dissertações que articulam Comunicação/Feminismo, no levantamento de Fernanda Coruja (2018), priorizam a mídia tradicional (cinema, revistas, jornal, televisão). Consequentemente, até 2015, a internet ainda configurava um objeto minoritário diante da predominância da mídia tradicional quando o atravessamento dos feminismos é privilegiado. Isto permite pensar que se abre a

32 Entre essas ações, destacam-se: a manifestação contra a aprovação do projeto de lei 5069/2013 que cria barreiras para que as mulheres vítimas de estupro tenham acesso legal ao aborto, realizada em 21 de outubro de 2015, em Brasília; a Marcha das Margaridas; a Marcha das Mulheres Negras; a Marcha do Empoderamento Crespo; a criação das hashtags \#enemfeminista e \#feminismonoenem, em decorrência do tema da redação, a violência contra as mulheres, do Exame Nacional de Ensino Médio, desse mesmo ano; e também \#primeiroassedio e \#meuamigosecreto.

Dossiê Crise, Feminismo e Comunicação - https://revistaecopos.eco.ufrj.br/

ISSN $2175-8689$ - v. 23, n. 3, 2020

DOI: 10.29146/eco-pos.v23i3.27643 
partir daí um potente horizonte de estudos e a possibilidade de delimitar uma nova arrancada. ${ }^{33}$

Ao longo da segunda década do século XXI, movimentos, organizações e coletivos feministas se expandiram consideravelmente na sociedade contemporânea como um todo. Fenômeno muito visível, também, no Brasil. A participação de jovens, tanto dos estratos médios quanto dos populares, com formação acadêmica ou não, de mulheres negras, indígenas, das periferias, das metrópoles e do campo vêm revitalizando e ampliando as práticas políticas feministas. Nesse processo, é inegável o papel exercido pelas tecnologias de informação e comunicação e pela internet, constituindo um espaço de atuação política que produz inúmeros desafios tanto para a ação coletiva quanto para a reflexão feminista.

Desde muito cedo a ação feminista percebeu a importância dos meios de comunicação na sociedade, desenvolvendo uma relação em dupla via: por um lado, a crítica e a reflexão sobre a atuação dos meios na construção simbólica de papeis e estereótipos de gênero - incluindo a representação política das mulheres - e, de outro, seu uso alternativo no combate aos discursos dominantes, sexistas, e à produção de discursos feministas. Enfim, desde o início, tratou-se de compreender o uso da mídia como mecanismo de ação política. No caso brasileiro, o relato dos anos 1970/1980 já demonstrou isso.

Hoje, inúmeras experiências de ativismo, sejam individuais ou grupais, usam a internet para minar representações e estereótipos misóginos correntes na mídia mainstream sobre as mulheres e, também, sobre identidades LGBTQI+. Destaca-se, no contexto contemporâneo, a vitalidade do ativismo de mulheres negras. Todas essas práticas de comunicação colaboram na difusão de múltiplas vozes que combatem comportamentos sexistas, em suas intersecções com raça e

33 Obviamente, não se desconhece a circulação de artigos científicos sobre o tema, de origens disciplinares variadas.

Dossiê Crise, Feminismo e Comunicação - https://revistaecopos.eco.ufrj.br/

ISSN $2175-8689$ - v. 23, n. 3, 2020

DOI: 10.29146/eco-pos.v23i3.27643 
classe, num cenário político radicalmente conservador, sobretudo, após as eleições presidenciais de $2018 .^{34}$

Tais práticas de ativismo político feminista na blogosfera configuram-se em experiências que não só renovam a energia dos movimentos feministas, mas se constituem em potentes tentativas para estabelecer laços com redes feministas transnacionais, bem como solidariedade entre feminismos do Sul e do Norte. Se, de um lado, a visibilidade dessas vozes na dinâmica do espaço público não é suficiente como indicador de uma comunicação democrática, de outro, fortalece a difusão e a popularização de feminismos diversos. Contudo, não podemos ignorar que as tecnologias digitais contêm possibilidades contraditórias que revelam continuidades das relações de poder e de exclusão (Wajcman, 2012).

Em direção contrária ao ativismo feminista, as plataformas digitais também dão vazão à raiva, ao ódio e desprezo às mulheres e às identidades LGBTQI+, em confrontação a um processo de reconhecimento da diversidade afetiva, sexual e de gênero, em andamento. E, dentro dele, nota-se a ascensão de um enfurecido discurso antifeminista. ${ }^{35}$ Entre os diversos ataques de misoginia escancarada dos últimos tempos, a tentativa de impedir uma menina de 10 anos, violentada pelo tio, de ter acesso ao aborto seguro, é mais um flagrante do retrocesso e crise em que vivemos. ${ }^{36}$ E, sem dúvida, as redes e plataformas digitais como Twitter, Facebook e YouTube, alavancaram e promoveram a movimentação de católicos ${ }^{37}$, evangélicos e bolsonaristas, todos antiaborto, na construção de um discurso de ódio

\footnotetext{
${ }^{34}$ Importante destacar o movimento \#EleNao, liderado por mulheres, que teve organização nas redes sociais, mas também foi às ruas, realizando uma manifestação popular, de caráter nacional e internacional, no dia 29 de setembro de 2018. Porém, não desconheço que alguns autores (Miskolci et al, 2017; Baliero, 2018) demonstram que uma série de contraofensivas foram sendo gestadas desde o início deste milênio, ganhando ainda mais força na década de 2010, com o objetivo de barrar avanços relativos a direitos sexuais e reprodutivos no país, configurando-se inclusive como ameaça à liberdade intelectual e artística.

35 A extremista Sara Winter é uma representante dessa faceta. Ver https://brasil.elpais.com/brasil/2020-06-25/sara-winter-a-extravagante-ativista-que-encarna-adisputa-entre-bolsonaro-e-o-supremo.html Acesso em 2 de set. 2020.

36Ver $\quad$ https://piaui.folha.uol.com.br/menina-o-poder-e-o-direito/; https://brasil.elpais.com/brasil/2020-08-18/menina-estuprada-sofreu-acosso-deultraconservadores-ate-dentro-de-hospital.html?rel=listapoyo. Acesso em 1 de set. 2020.

37 Ver atuação de "católicos" contra "católicas" em https://g1.globo.com/sp/saopaulo/noticia/2020/10/27/tribunal-de-justica-de-sp-proibe-ong-catolicas-pelo-direito-de-decidirque-defende-aborto-legal-de-usar-catolicas-no-nome.ghtml. Acesso em 9 de dez. 2020.
}

Dossiê Crise, Feminismo e Comunicação - https://revistaecopos.eco.ufrj.br/

ISSN $2175-8689$ - v. 23, n. 3, 2020

DOI: 10.29146/eco-pos.v23i3.27643 
antifeminista. Trata-se de um tema crucial na atualidade e que necessita maior destaque na agenda de pesquisa. ${ }^{38}$

Enfim, as relações entre a Comunicação e as questões de gênero, no Brasil, foram expandindo o escopo de suas análises sobre estereótipos, papéis sociais e representações das mulheres para os estudos de audiência/recepção/consumo e para a inclusão paulatina da temática sobre identidades LGBTQI+ na mídia; sobre o uso, em especial, de formas de imprensa alternativa e independente na promoção das lutas feministas para uma nascente atenção sobre o ativismo, sobretudo, de jovens na mídia e nas redes sociais digitais, engajadas, de distintos modos, aos feminismos contemporâneos (comunitários, metropolitanos, periféricos, decolonial, negro, indígena, entre outros). Nota-se que, na conjuntura atual, é obrigatório adensar o eixo de análise sobre esses novos ativismos midiáticos. Em especial, se o foco estiver no espaço da internet que tem sido visto frequentemente sob um horizonte otimista e com reiterado potencial liberador. De toda forma, esse objeto de estudo tem chances de alavancar mais uma interlocução e reciprocidade entre o Sul e o Norte.

Todas essas frentes de atuação e reflexão configuram indícios esperançosos de que o "ruído teórico" causado pelos feminismos ainda têm muito a repercutir na Comunicação, embora o futuro seja uma incógnita, diante do recrudescimento conservador e, inclusive, perseguição e autoexílio de militantes das causas feministas e LGBTQI+, desencadeados a partir do resultado das últimas eleições presidenciais. ${ }^{39} \mathrm{Em}$ termos mais gerais, assinalo que, a partir da primeira década do século XXI ou terceiro impulso, as relações entre os estudos de comunicação e de gênero manifestam-se, através de arranjos específicos entre categorias e conceitos dos respectivos campos, produzindo objetos de estudos e perspectivas particulares que, talvez, sinalizem a embrionária formação de estudos culturais feministas, entre nós.

\footnotetext{
38 Sob orientação de João Freire Filho, indica-se a dissertação de Júlia dos Anjos, Megeras (In) Domadas: discurso de ódio antifeminista nas redes sociais (Comunicação/UFRJ, 2019). ${ }^{39}$ Jean Wyllys e Debora Diniz são exemplos dessa situação. Ver Rosana Pinheiro-Machado, Fuga de cérebros e autoexílio: governo Bolsonaro reacende o trauma da ditadura. https://theintercept.com/2019/08/05/fuga-de-cerebros-e-autoexilio-governo-bolsonaroreacende-o-trauma-da-ditadura/ Acesso em 2 de set. 2020.
}

Dossiê Crise, Feminismo e Comunicação - https://revistaecopos.eco.ufri.br/

ISSN 2175-8689 - v. 23, n. 3, 2020

DOI: 10.29146/eco-pos.v23i3.27643 


\section{Referências bibliográficas}

BALIEIRO, Fernando. "Não se meta com meus filhos": a construção de um pânico moral da criança sob ameaça. Cadernos Pagu, 53, 2018, s/p.

BENETTI, Fernando. A bicha louca está fervendo: uma reflexão sobre a emergência da Teoria Queer no Brasil (1980-2013). TCC em História, UDESC, Florianópolis, 2013.

BOSI, Eclea. Prefácio à primeira edição. In BUITONI, Dulcília S. Mulher de papel: a representação da mulher na imprensa feminina brasileira. São Paulo: Summus Editorial, 2009, p.17-19.

BOSI, Eclea. Cultura de massa e cultura popular: Leituras de operárias. Petrópolis: Vozes, 1978.

BUITONI, Dulcília S. Mulher de papel: a representação da mulher na imprensa feminina brasileira. São Paulo: Summus Editorial, 2009, p. 11-16.

BRUSCHINI, Cristina; PINTO, Celi Regina (orgs.). Tempos e lugares de gênero. São Paulo: Editora 34, 2001.

CALIGARIS, Contardo. A turba da Uniban. Folha de São Paulo, 5/11/2009. Disponível em: https://www1.folha.uol.com.br/fsp/ilustrad/fq0511200929.htm. Acessado em: 18 fev 2019.

COUTINHO, Lucia. Antônia sou eu, Antônia é você: Identidade de mulheres negras na televisão brasileira. Dissertação de Mestrado, PUCRS, 2010.

CORUJA, P. Comunicação e feminismo: um panorama a partir da produção de teses e dissertação do campo da comunicação entre 2010-2015. Revista Ártemis - Estudos de Gênero, Feminismos e Sexualidades, v. 25, n. 1, p. 148-162, 1 ago. 2018.

ESCOSTEGUY, Ana Carolina. A contribuição do olhar feminista. Intexto, 1 (3), 1998, pp. 111.

Os estudos de recepção e as relações de gênero: algumas anotações provisórias. Ciberlegenda, Rio de Janeiro, 7, 2002, s/p.

ESCOSTEGUY, Ana Carolina; MESSA, Márcia. Os estudos de gênero na pesquisa em comunicação no Brasil. In ESCOSTEGUY, A. C. (orgs) Comunicação e Gênero: a aventura da pesquisa. Porto Alegre: EDIPUCRS, 2008. E-book em acesso livre http://www.pucrs.br/edipucrs/comunicacaoegenero.pdf

ESCOSTEGUY, A. C. (org.) Comunicação e Gênero: a aventura da pesquisa. Porto Alegre: EDIPUCRS, 2008. E-book em livre http://www.pucrs.br/edipucrs/comunicacaoegenero.pdf

Dossiê Crise, Feminismo e Comunicação - https://revistaecopos.eco.ufrj.br/

ISSN 2175-8689 - v. 23, n. 3, 2020

DOI: 10.29146/eco-pos.v23i3.27643 
Pensando as relações entre mídia e gênero através de histórias pessoais: o caso brasileiro. Derecho a Comunicar, Cidade do México, n. 4, 2012, p. 174-186.

FERREIRA, Ceiça. Lacunas nos estudos de comunicação e cinema no Brasil: feminismo (intersecções de gênero e raça) e recepção fílmica. Matrizes, v. 11, n. 3, 2017, pp 169-195.

GOMES, Carla; SORJ, Bila. Corpo, geração e identidade: a Marcha das vadias no Brasil. Revista Sociedade e Estado, 29 (2), 2014, pp. 433-447.

GROSSI, Miriam. De Angela Diniz a Daniela Perez: a trajetória da impunidade. Estudos Feministas, n. 1, 1993, pp. 166-168.

HOLLOWS, Joanne. Feminismo, estudios culturales y cultura popular. Lectora, n. 11, 2005, p. $15-28$.

JACKS, Nilda; MENEZES, D.; PIEDRAS, Elisa. Meios e audiências: A emergência dos estudos de recepção no Brasil. Porto Alegre: Sulina, 2008.

LEAL, Tatiane. A mulher poderosa: construções da vida bem-sucedida feminina no jornalismo brasileiro. Dissertação de Mestrado, Programa de Pós-Graduação em Comunicação e Cultura, UFRJ, 2015.

LURZER, Carolina Justo von. Oportunidades, ausencias y desafios. Los estudos de comunicación y género en Argentina. Revista Latino-Americana de Ciencias de la Comunicación - Revista ALAIC, vol 15, n. 29, 2018, pp. 260-273.

MARTINEZ, Monica; LAGO, Cláudia; LAGO, Mara. Estudos de gênero na pesquisa em jornalismo no Brasil: uma tênue relação. Revista FAMECOS, 23 (2), 2016, s/p.

MATOS, Marlise. Teorias de gênero ou teorias e gênero? Se e como os estudos de gênero e feministas se transformaram em um campo novo para as ciências. Estudos Feministas, Florianópolis, 16 (2), 2008, pp. 333-357.

MEIRELLES, Clara. Prazer e resistência: A legitimação do melodrama nos contextos acadêmicos. Dissertação de Mestrado, Comunicação e Cultura, Universidade Federal do Rio de Janeiro, 2009.

MESSA, Márcia. As mulheres só querem ser salvas: Sex and the City e o pós-feminismo. Dissertação de Mestrado, PPGCOM/PUCRS, 2006.

McROBBIE, Angela. Post-feminism and popular culture: Bridget Jones and the new gender regime. In: CURRAN, J.; MORLEY, D. (eds) Media and cultural theory. Londres: Routledge, 2006, p. 59-69.

MISKOLCI, Richard; CAMPANA, Maximiliano. "Ideologia de gênero": notas para a genealogia de um pânico moral contemporâneo. Revista Sociedade e Estado, 332 (3), 2017, pp. 725-747.

MONTORO, Tânia; FERREIRA, Ceiça. Gênero e raça: um mergulho nos estudos de comunicação e recepção. Animus, vol. 13, n 25, 2014, pp. 1-24.

Dossiê Crise, Feminismo e Comunicação - https://revistaecopos.eco.ufri.br/

ISSN $2175-8689$ - v. 23, n. 3, 2020

DOI: 10.29146/eco-pos.v23i3.27643 
PINTO, Celi Regina. Uma história do feminismo no Brasil. Editora Fundação Perseu Abramo, São Paulo, 2003.

RIBEIRO, Djamila. O que é lugar de fala? Belo Horizonte: Letramento, 2017.

RICHARD, Nelly (2002) Feminismo e desconstrução: novos desafios críticos. In: RICHARD, N. Intervenções críticas: Arte, cultura gênero e política. Belo Horizonte: UFMG, 2002, pp. 156-172.

RODRIGUES, Cristiano; ASSIS, Mariana. (2018) Academic Feminism and Exclusion in Brazil: Bringing Back Some of the Missing Voices. In: Kahlert H. (eds) Gender Studies and the New Academic Governance. Springer VS, Wiesbaden. https://doi.org/10.1007/978-3-658-19853-4 8

RUBIM, Lindinalva. A representação feminina na TV brasileira. Trabalho apresentado no X Congresso da Compós, Brasília, 2001. Disponível em: http://www.compos.org.br/data/biblioteca 1324.pdf

RUDIGER, Francisco; ESCOSTEGUY, Ana Carolina. Brazilian Research in Communication: Historical Synopsis and Reflexive Trends of Academic Work in a Emerging Country. In AVERBECK, Stefanie. Kommunikations-wissenschaft im internationalen Vergleich Trnasnationale Perspektiven. Bremen, Springer VS, 2017, pp. 359-382.

SANTOS, Giselle Cristina dos Anjos. Os estudos feministas e o racismo epistêmico. Revista Gênero, v. 16 (2), 2016, pp. 7-32.

SARQUES, Jane. A ideologia sexual dos gigantes. Goiânia: Universidade Federal de Goiás, 1986.

SCHMIDT, Simone Pereira. 0 feminismo nas páginas dos jornais: revisitando o Brasil dos anos 70 aos 90. Revista Estudos Feministas, vol. 8, n. 2, 2000, p. 77-90.

SIFUENTES, Lírian; SILVEIRA, Bruna; OLIVEIRA, Janaína. Mídia e relações de gênero nas publicações feministas brasileiras. Derecho a comunicar, n. 4, jan.abr, 2012, p.187-203.

SILVA, Fernanda Nascimento da. Bicha (nem tão má) - LGBTs em telenovelas. Rio de Janeiro: Multifoco, 2015.

SILVA, Lourdes; JOHN, Valquíria. Identidades de gênero nos estudos de recepção de telenovela: um olhar sobre a produção stricto sensu da última década. Revista FAMECOS, vol. 23, n. 2, maio-jun-jul-ago, 2016, s/p.

SOIHET, Raquel. Zombaria como arma antifeminista: instrumento conservador entre libertários. Estudos Feministas, 13 (3), 2005, pp. 591-611.

SORJ, Bila. Depoimento. In HOLLANDA, Heloísa Buarque de (org.). Explosão feminista: arte, política e universidade. São Paulo: Companhia das Letras, 2018, pp. 445-452.

Dossiê Crise, Feminismo e Comunicação - https://revistaecopos.eco.ufrj.br/

ISSN $2175-8689$ - v. 23, n. 3, 2020

DOI: 10.29146/eco-pos.v23i3.27643 
TELES, Amélia; LEITE, Rosalina. Da guerilha à imprensa feminista: a construção do feminismo pós-luta armada no Brasil (1975-1980). São Paulo: Intermeios, 2013.

TOMAZETTI, Tainan. Genealogias dissidentes: os estudos de gênero nas teses e dissertações em comunicação no Brasil (1972-2015). FABICO/UFRGS, Porto Alegre, 2019.

WAJCMAN, Judy. TIC e inequidad: ganancias en red para las mujeres?. Revista Educación $Y$ Pedagogía, Vol 24 (62), 2012, pp. 117-134.

WILLIAMS, Raymond. (2011). 0 futuro dos estudos culturais. In: Williams, R. Política do modernismo - Contra os novos conformistas. São Paulo: UNESP. 